\title{
DETECTION OF VIRAL PARTICLES IN FECES OF YOUNG DOGS AND THEIR RELATIONSHIP WITH CLINICAL SIGNS
}

\author{
Alicia N. del Amo ${ }^{1^{*}}$; Adriana N. Aprea ${ }^{1}$; Miguel A. Petruccelli ${ }^{2}$ \\ ${ }^{1}$ Cátedra de Clínica de Pequeños Animales. ${ }^{2}$ Servicio Central de Microscopía Electrónica, Facultad de \\ Ciencias Veterinarias, Universidad Nacional de La Plata, República Argentina
}

Submitted: June 22, 1998; Returned to authors for corrections: September 29, 1998; Approved: August 09, 1999

\begin{abstract}
Gross and light microscopic studies of 100 stool specimens of young dogs were carried out. Viral particles were detected in $31 \%$ of the analized samples using negative contrast electron microscopic diagnostic technique. Parvo-like virus, corona-like virus and other non-identified particles were observed in $17 \%, 7 \%$ and $2 \%$ of the samples, respectively. Parvo-like and corona-like viruses were found together in 5\% of the samples. More than half $(58.82 \%)$ of the positive parvo-like virus specimens were from dogs aged between 6 weeks and 6 months. $42.85 \%$ of the corona-like virus positive samples were detected in dogs between 6 weeks and 6 months and a similar percentage was found in dogs older than six months of age. Dual infections with parvo-like and corona-like viruses were observed in $5 \%$ of the samples. Unidentified virus-like particles were found in two specimens. $80.63 \%$ of the samples containing viral particles were obtained from dogs with diarrhea.
\end{abstract}

Key words: Parvo-like virus, corona-like virus, diarrhea, dogs, electron microscopy

\section{INTRODUCTION}

Parvovirus (CPV) and coronavirus (CCV) have clearly been established as causes of enteritis and diarrhea in dogs and cats $(5,8,11,13,15)$. Other viruses, like rotavirus, astrovirus, adenovirus, paramixovirus, calicivirus and picornavirus have been also observed in canine feces $(4,6,9,13,17)$. Some of these viruses were found with equal frequency in normal feces and feces from animals with diarrhea, and have not been established as enteropathogens yet (11). Rotavirus has been recognized as one of the most important cause of neonatal diarrhea in humans, cattle, swine, sheep and mice $(2,11)$. In dogs rotavirus has been associated with a neonatal transitory diarrhea with lethal course in a few of them (9). An incidence of anti-rotavirus antibodies has been demonstrated in $79 \%$ to $86 \%$ of the animals $(9,11)$. These findings suggest that many animals present subclinical infections during their lives (9).

The incidence of these viruses in Argentina is not known. However, in a preliminary study carried out by the authors on 42 samples of canine feces, no rotavirus particle was detected (1).

The most frequent diagnostic methods for titration of viruses in feces are hemagglutination tests (HA) and enzime-linked immunosorbent assays (ELISA). $\mathrm{CPV}, \mathrm{CCV}$ and other enteric viruses can be diagnosed

\footnotetext{
* Corresponding author. Mailing address: Cátedra de Clínica de Pequeños Animales, Facultad de Ciencias Veterinarias, Universidad Nacional de La Plata. C.C. 296 (1900) La Plata. República Argentina. E-mail: adelamo@fcv.medvet.unlp.edu.ar
} 
by isolation from feces, detection by electron microscopy and identification by immune electron microscopy $(3,11)$.

Serologic tests to detect anti-rotavirus antibodies have been used in research but are not currently available for clinical diagnosis (11).

The objective of the present paper was to relate the clinical features of diarrhea of young dogs with the recognition of viral particles in the feces, through electron transmission microscopy. In order to establish other causes of diarrhea examination of feces through optical microscopy were also carried out.

\section{MATERIALS AND METHODS}

Fecal samples. The fecal samples (n: 100) were obtained from dogs submitted to the Small Animal Clinic of La Plata National University for clinical examination. Sixty two had diarrhea as the main problem.

The animals aged between 15 days and 12 months. Dogs were submitted to a complete clinical examination. These findings as well as vaccination status were registered in previously designed protocols.

Gross and microscopic examination of fecal samples. Gross examination of the feces was performed taking into account colour, consistency, presence of mucus and fresh blood. The light microscopy included the evaluation of fatty globules by Sudan III in 95\% ethylic alcohol (16). A smear was stained with one drop of New Methylen Blue to count leukocytes, other cells and fibers. Direct coproparasitological examination was also included for identification of tapeworms, ascarids, hookworms, coccidia, oocysts and flagellated trophozoites of giardias.

Negative contrast electron microscopy (1). $1 \mathrm{ml}$ of each fecal sample was homogeneized with $10 \mathrm{ml}$

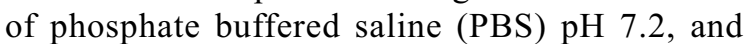
centrifuged at $8,000 \mathrm{~g}$ during 15 minutes at $4^{\circ} \mathrm{C}$. The sediment was discarded and a second centrifugation with a Beckman L7-65 (rotor 70.1 Ti) ultracentrifuge at 45,000 r.p.m. during two hours at $4{ }^{\circ} \mathrm{C}$ was performed. The sediment was resuspended 1:1 with PBS, and one drop was placed on a cooper grid (carbon substrate), and allowed to stand one minute. The excess was removed with a piece of filter paper. Two grids were negatively stained with $2 \%$ phosphotungstic acid, pH 7 during 1 minute, and examined with a JEM 1200 EX II (Jeol) electron microscope. Each grid was scanned among 15 minutes before recorded as negative. The morphological identification was done according to the morphology and size of the viral particles (14).

\section{RESULTS}

The dogs were divided in three different groups according to their ages: Group 1: 1week to 6 weeks; Group 2: 6 weeks to 6 months and Group 3: 6 months to 12 months.

Viruses were detected in 31 fecal samples (31\%). $\mathrm{CCV}$-like viruses (Fig 1.) were found in 12 samples (12\%), and $C P V$-like viruses (Fig. 2) were observed in 17 samples $(17 \%)$.

The distribution of the viral findings according to the age of the animals is shown in Table 1 .

The higgest frquency of viruses was observed in animals of Group 2: 10 positive samples $(10 \%)$ for $C P V$-like viruses and $3(3 \%)$ for $C C V$-like viruses.

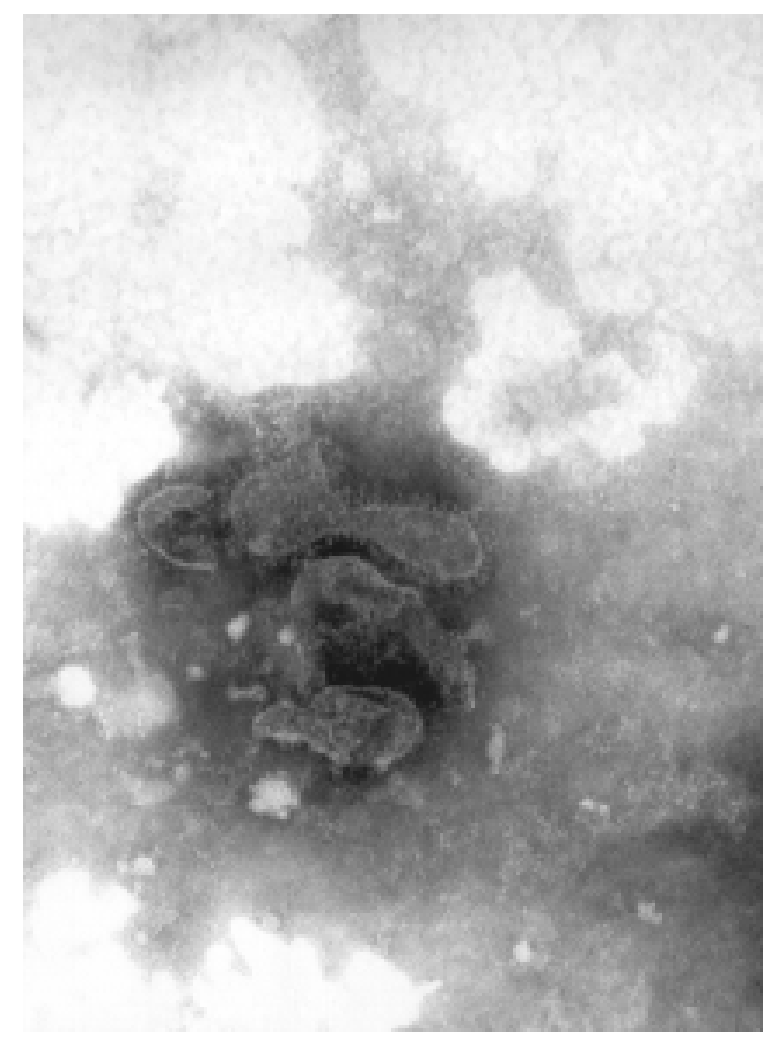

Figure 1 - Electron microscopy showing a corona-like virus, $\mathrm{x}$ $222 \mathrm{~K}$ (negative strain). 
Table 1 - Parvo-virus like (CPV) and corona-virus like (CCV) particles in fecal samples of dogs with and without diarrhea.

\begin{tabular}{|c|c|c|c|c|c|c|c|c|c|c|c|c|c|}
\hline \multicolumn{14}{|c|}{ Ages of dogs } \\
\hline \multirow{3}{*}{ Virus detected } & \multicolumn{4}{|c|}{$1 w-6 w$} & \multicolumn{4}{|c|}{$6 w-6 m$} & \multicolumn{4}{|c|}{$6 m-12 m$} & \multirow{3}{*}{$\frac{\text { Total }}{\%}$} \\
\hline & \multicolumn{2}{|c|}{ Normal } & \multicolumn{2}{|c|}{ Diarrhea } & \multicolumn{2}{|c|}{ Normal } & \multicolumn{2}{|c|}{ Diarrhea } & \multicolumn{2}{|c|}{ Normal } & \multicolumn{2}{|c|}{ Diarrhea } & \\
\hline & $\mathrm{n}$ & $\%$ & $\mathrm{n}$ & $\%$ & $\mathrm{n}$ & $\%$ & $\mathrm{n}$ & $\%$ & $\mathrm{n}$ & $\%$ & $\mathrm{n}$ & $\%$ & \\
\hline CPV-L & 1 & $1 \%$ & 5 & $5 \%$ & 1 & $1 \%$ & 9 & $9 \%$ & - & - & 1 & $1 \%$ & $17 \%$ \\
\hline CCV-L & 1 & $1 \%$ & - & - & 1 & $1 \%$ & 2 & $2 \%$ & - & - & 3 & $3 \%$ & $7 \%$ \\
\hline $\mathrm{CPV} / \mathrm{CCV}-\mathrm{L}$ & - & - & - & - & 1 & $1 \%$ & 4 & $4 \%$ & - & - & - & - & $5 \%$ \\
\hline Unidentified & - & - & - & - & 1 & $1 \%$ & 1 & $1 \%$ & - & - & - & - & $2 \%$ \\
\hline Total & 2 & $2 \%$ & 5 & $5 \%$ & 4 & $4 \%$ & 16 & $16 \%$ & - & - & 4 & $4 \%$ & $31 \%$ \\
\hline
\end{tabular}

W: week- m: month

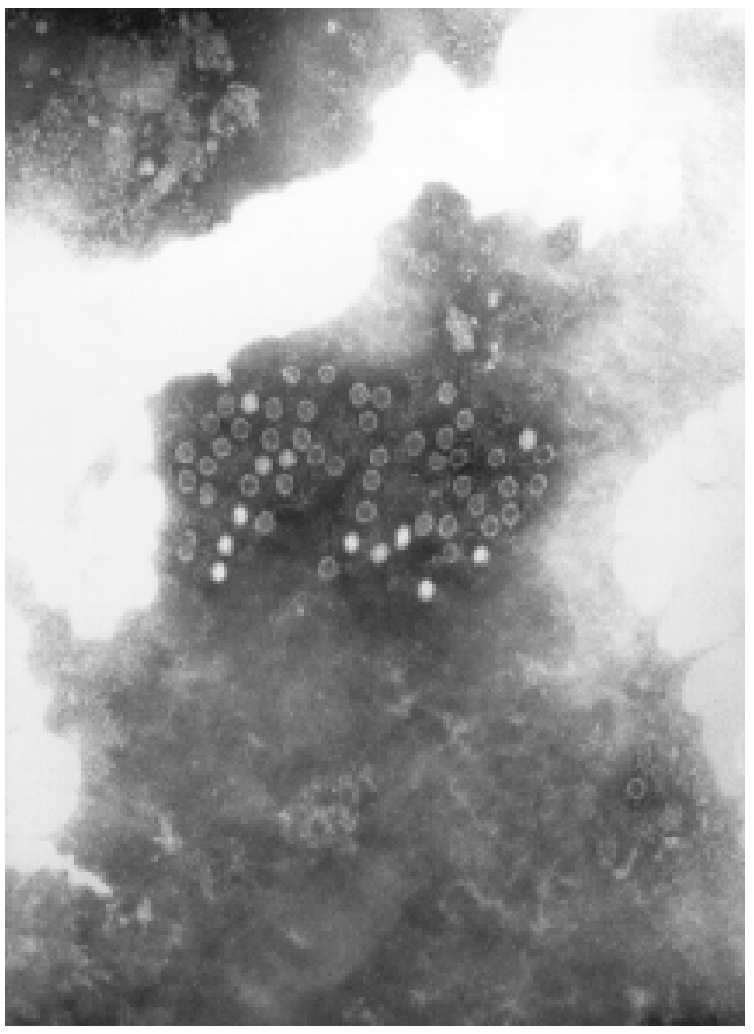

Figure 2 - Electron microscopy showing a group of parvo-like virus, $\mathrm{x} 170 \mathrm{~K}$ (negative strain).

Five dual infections (5\%) with CPV-like and CCV-like viruses were also observed. They were detected in animals aged between 6 weeks and 6 months. Unidentified virus-like particles were found in two specimens $(2 \%)$.
Table 2 - Fecal consistency and body temperature of 31 dogs with CPV-like and CCV-like viral particles in their feces.

\begin{tabular}{lcccc}
\hline Consistency & Parvo-like & Corona-like & $\begin{array}{c}\text { Parvo \& } \\
\text { corona-like }\end{array}$ & unidentified \\
\hline Normal & 2 & 2 & 1 & 1 \\
Soft & 4 & 3 & - & 1 \\
Liquid & 11 & 2 & 4 & - \\
Body & & & & \\
temperature & 15 & 5 & 2 & 1 \\
Normal T & & 2 & 3 & 1 \\
Fever & 2 & 2 & &
\end{tabular}

The relationship between feces consistency, body temperature of the dogs and presence of viral particles is presented in Table 2 .

The microscopic examination indicated that eleven positive fecal samples contained also a few nematod eggs (ascarids and hookworms). Only one sample had tapeworm eggs, and four presented giardias. Fatty globules and leucocytes counts were normal in all samples. Blood was found in 11 of the positive samples and 7 contained mucus.

None of the dogs had been immunized against canine parvovirus or corona-virus.

\section{DISCUSSION}

The identification of the CPV in feces can be carried out only during the elimination period of the viruses, which occurs between the $3^{\text {nd }}$ and $9^{\text {th }}$ day of infection (7). As serological or molecular studies were 
not done, the low frquency observed in our study may be artificial.

Eighty point sixty three percent of the samples that presented viral particles belonged to dogs with soft $(25.80 \%)$ and liquid $(54.83 \%)$ feces. As fatty globules and leukocytes counts were normal, it can be assumed that diarrhea was not a consequence of maldigestion syndromes or bacterial infection (17).

Among 17 fecal samples with $C P V$-like particles, 2 presented normal consistency and 15 were liquid, six of them were also positive for ascarids, and 1 for flagellated trophozoites of giardias because they were in a few number, it was assured that they didn't produce disease.

Two normal, three soft and two liquid feces were found in the $C C V$-like positive fecal samples. This is in agreement with the findings by Pollock and Carmichael (9) who concluded that probably there is not a narrow association between $\mathrm{CCV}$ and severe gastroenteritis in dogs.

The results of the present study, showing a low incidence of $C C V$-like infection, may be artificial. This may be due to some problems associated with identification of this virus. The most important characteristic of this virus is the fragile envelope, whose integrity can be affected by the lenght of storage and by the handling of the sample. Since there was a limited control over the time of storage of the samples, a consequent loss in integrity of CCV could have interfered with the unequivocal identification of the virus (14).

Two dogs with $C P V$-like particles in their feces were febrile and 9 of them were depressed and anorexic. These findings are coincident with the results reported by Swango (12), who found that depression and fever in CPV or CCV infected animals are common.

Dual presence of $C P V$-like and $C C V$-like viruses ocurred in $5 \operatorname{dogs}$ ( $16.12 \%$ of the positive samples). This result disagrees with those reported by Scherding (11), who said that the dual infection ocurrs in up to 25 per cent of cases of canine viral enteritis. The dogs with dual infection were more seriously ill than those infected with $C P V$-like or $C C V$-like viruses alone.

Fresh blood was found in $29.41 \%$ of the fecal samples containing $C P V$-like particles. This finding is not coincident with our preliminary report $(18.60 \%)$ (1) and with Pollock and Carmichael (9), who found bloody diarrhea in $50 \%$ of the $C P V$ infected dogs.

A high percentage of positive samples for $C P V$ - like particles was found in puppies under 5 months of age $(52.94 \%)$, confirming the age susceptibility to $C P V$-like infection described by Hammond and Timoney (6). Dehydration and acidosis develop more quickly in puppies than in older animals. The puppies of this study experienced a severe illness, were anorectic and depressed, and their feces were liquid.

In the present study, $C P V$-like particles were found to be more closely associated with canine gastroenteritis than $C C V$-like particles. This is coincident with the results of Roseto et al. (10), who found a prevalence of this virus associated with gastroenteritis.

In this study, rotavirus-like particles were not identified in the samples. Further surveys are needed to investigate the prevalence of this virus.

\section{RESUMO}

\section{Detecção de partículas virais em fezes de cães jovens e sua relação com sinais clínicos}

Foram analisadas macroscópica e microscopicamente 100 amostras de fezes de cães jovens colhidas em ambulatório clínico. Através de microscopia eletrônica de contraste negativo, foram detectadas partículas virais em $31 \%$ das amostras de fezes examinadas. Do total de amostras onde foram detectadas partículas virais, $17 \%$ continham partículas parvo-like, $7 \%$ continhan partículas corona-like virus e $2 \%$ continham partículas com morfologia não característica. Em 5\% das amostras foi detectada a presença simultânea de partículas parvo-like e corona-like. Do total de amostras de fezes contendo partículas parvo-like, $58,82 \%$ eram de cães com 6 semanas a 6 meses de idade, o que também foi observado em $42,85 \%$ das amostras de fezes contendo partículas corona-like foram cães entre 6 semanas e 6 meses e um número semelhante foi encontrado em cães de mais de 6 semanas de idade. Uma dupla infecção de parvo-like virus e corona-like virus, foi confirmada em $5 \%$ dos especimens. Partículas "virus-like" não identificadas foram encontradas em 2 indivíduos Das amostras com identificação de partículas virais, $80,64 \%$ pertenceram a cães com diarréia.

Palavras-chave: parvo-like virus, corona-like virus, diarréia, cães, microscopia eletrônica 


\section{REFERENCES}

1. Aprea, A.N.; del Amo, A.N.; PetruccelliI, M.A. Identificación de partículas virales en materia fecal de caninos por microscopía electrónica. Su relación con cuadros clínicos de diarrea. Estudio preliminar. Selecciones Veterinarias, 5: 329-332, 1997.

2. Donelli, G.; Superti, F. The rotavirus genus. Comparative Immunology Microbiol. Infect. Dis. 17: 3-4, 1994.

3. Dow, S.W. Acute medical diseases of the small intestine. In: Tams, T.R.(ed): Handbook of Small Animal Gastroenterology. Ed. W.B. Saunders Company. Philadelphia,1996, pp. 245-266.

4. Fulton, R.W.; Johnson, C.A.; Pearson, N.J. et al. Isolation of a rotavirus from a newborn dog with diarrhea. Am. J. Vet. Res. 42: 841-843,1981.

5. Guilford, W.E.; Strombeck, D.R. Gastrointestinal Tract Infections, Parasites and Toxicoses. In Strombeck, D.R and Guilford, W.E.(ed): Strombeck's Small Animal Gastroenterology. Ed. W.B. Saunders Company. Philadelphia, 1996, pp. 411-432.

6. Hammond, M.M.; Timoney, P. An electron microscopic study of viruses associated with canine gastroenteritis. Cornell Vet. 73: 82-97, 1983.

7. Latour, S. Mortalité et morbidité du chiot. Pathologie de groupe. Rec. Méd. Vét. Special Croissance du Chiot. September/Octobre: 571-575, 1996.

8. Martincalvo, M.; Marcotegui, M.; Simarro, I. Canine coronavirus characterization in Spain. Epidemiological aspects. J. Vet. Med. B. 41: 4,249-256, 1994.

9. Pollock, R.; Carmichael, L.E. Enteritis viral canina. In Greene, C.E. (ed.): Enfermedades infecciosas. Perros y gatos. Ed. Interamericana. México, 1992, pp. 280-300.

10. Roseto, A.; Lema, F; Cavalieri, F. Electron Microscopy detection and characterization of viral particles in dog stool. Arch. Virol. 66: 89-93, 1980.

11. Sherding, R. Enfermedades del intestino delgado. In Ettinger, S.J. (ed.): Tratado de Medicina Interna Veterinaria. Ed. Intermédica. Bs.As, 1992, pp. 1392-1467.

12. Swango, L.J. Canine viral diseases. In: Ettinger, S.J. y Feldman, E.C. (eds): Textbook of Veterinary Internal Medicine. Ed. W.B. Saunders Company. Philadelphia, 1995, pp. 398-409.

13. Vieler, E.; Herbst, W. Elektronenmikroskopischer virusnachweis in Kotproben durchfallkranker Hunde. Tierärzlt Prax 23: 66-9, 1995.

14. Webstek, R.G.; Granoff, A. Encyclopedia of Virology. Vol I-III, Ed. Academic Press. London pp. 255; pp. 1062, 1994.

15. Wege, H. Immunopathological aspects of coronavirus infections. Springer Semin Immunopathol 17: 133-148, 1995.

16. Willard, M.D. Afecciones gastrointestinales, pancreáticas y hepáticas. In: Willard, M.D.; Tvedten, H. y Turnwald, G. (eds): Diagnóstico Clínico Patológico Práctico en los Animales Pequeños. Ed. Intermédica. Buenos Aires, 1993, pp. 213-257.

17. Williams, F.P. Astrovirus-like, coronavirus-like and parvovirus-like particles detected in the diarrheal stools of beagle pups. Arch. Virol. 66: 215-226, 1980. 